\title{
Penggunaan Media Sosial oleh Mahasiswa sebagai Upaya Sosialisasi Kegiatan Kuliah Kerja Nyata selama Pandemi COVID-19 di Kecamatan Pedurungan Semarang
}

\author{
Mutiawati Mandaka*1, Gatoet Wardianto², Ovariszar Bagus Affandi ${ }^{3}$ \\ 1,2,3Prodi Arsitektur, Fakultas Teknik, Universitas Pandanaran, Indonesia \\ *e-mail: mutia.mandaka@unpand.ac.id ${ }^{1}$,gatoetw@gmail.com ${ }^{2}{ }_{\text {_ovariszar@gmail.com }}^{3}$
}

\begin{abstract}
Abstrak
Tujuan dari Kuliah Kerja Nyata (KKN) adalah untuk mengimplementasikan ilmu yang diterima mahasiswa di bangku kuliah serta mendidik mahasiswa untuk bisa bersosialisasi dengan warga. Sejak pandemi COVID-19 muncul tahun 2020, pelaksanaan KKN berubah mengikuti protokol yang berlaku. Hal ini mengakibatkan pelaksanaan KKN semakin terbatas. Dengan pembatasan yang cukup ketat, mahasiswa yang terjun ke lapangan sangat dibatasi. Mereka menggunakan media sosial sebagai alternatif untuk melaksanakan program kegiatan KKN selama pandemi. Tujuan pengabdian ini adalah untuk mengetahui bagaimana mahasiswa menggunakan media sosial sebagai upaya mensosialisasikan kegiatan KKN selama pandemi di Kecamatan Pedurungan. Metode yang digunakan adalah dengan deskriptif kualitatifdengan studi literatur dan survei ke lapangan dan menyebarkan kuesioner untuk mendapatkan data. Hasilnya adalah media sosial yang digunakan untuk mensosialisasikan kegiatan KKN selama pandemi paling banyak digunakan adalah media whatshap 60\%, instagram 20\%, youtube 15\% dan 5\% menggunakan facebook. Media whatshap dianggap yang paling efektif dalam penyampaian sosialisasi kegiatan KKN di kecamatan Pedurungan.
\end{abstract}

Kata kunci: Kecamatan Pedurungan, Kuliah Kerja Nyata, Media Sosial, Sosialisasi

\begin{abstract}
The purpose of KKN is to implement the knowledge that students receive in college and educate students to be able to socialize with residents. Since the COVID-19 pandemic emerged in 2020, the implementation of KKN has changed following the applicable protocol. This has resulted in the implementation of KKN being increasingly limited. With quite strict restrictions, students who go into the field are very limited. They use social media as an alternative to carry out the Community Service Program during the pandemic. The purpose of this service is to find out how students use social media as an effort to socialize KKN activities during the pandemic in Pedurungan District. The method used is descriptive qualitative with literature studies and surveis to the field and distributing questionnaires to obtain data. The result is that the social media used to socialize KKN activities during the pandemic are the most widely used whatshap media $60 \%$, instagram 20\%, youtube 15\% and 5\% using facebook. Whatshap media is considered the most effective in delivering socialization of KKN activities in Pedurungan sub-district.
\end{abstract}

Keywords: KKN, Pedurungan District, Social Media, Socialization

\section{PENDAHULUAN}

Kuliah Kerja Nyata (KKN) adalah mata kuliah wajib yang harus ditempuh bagi mahasiswa Strata 1 (S1) dan merupakan salah satu syarat kelulusan bagi mahasiswa. KKN merupakan salah satu bentuk pengabdian masyarakat perguruan tinggi yang dilakukan oleh mahasiswa di bawah bimbingan dosen pembimbing lapangan dan pimpinan pemerintah daerah (Lurah). KKN merupakan kegiatan dalam kurikulum yang memadukan pelaksanaan Tri Dharma dengan cara memberikan pembelajaran dan pengalaman kerja kepada mahasiswa dalam kegiatan membangun masyarakat. Pelaksanaan kegiatan KKN yang mengharuskan mahasiswa beirnteraksi langsung dengan masyarakat menjadi terhambat sejak terjadinya pandemi COVID19 yang melanda seluruh dunia pada awal tahun 2020. Segala macam bentuk kegiatan diubah menjadi online atau daring, termasuk kegiatan KKN. Dengan pemanfaatan teknologi dan infromasi kegiatan KKN tetap dapat berjalan dengan menggunakan media sosial sebagai sarana penyampaian informasi dan program kerja yang telah ditentukan. 
Saat ini Internet merupakan media yang dimanfaatkan untuk berkomunikasi, dengan kecepatan akses yang tinggi mampu diakses di berbagai tempat dan dengan waktu yang tidak terbatas (Radovilsky, 2015) dalam Dewa Putu dan Made Dona (2021). Menurut Ardiana, dkk (2021) bahwa manusia memiliki keingitahuan yang terus berkembang, sehingga membuat manusia selalu ingin mengetahui perkembangan yang terjadi. Melalui internet, rasa ingin tahu tersebut menjadi terpenuhi. Dengan jangkauan jaringan yang luas, internet mampu menghubungkan jutaan komputer melalui berbagai tipe dan jenisnya (Kaunang et al., 2021). Marlina, dkk (2020) menyebutkan bahwa internet dapat dianalogikan sebagai jalan yang mampu mengkoneksikan semua lokasi di seluruh dunia. Hal ini sejalan dengan pendapat Ardila dkk (2020) bahwa internet sangat membantu dalam hal pertukaran informasi data baik untuk organisasi maupun individu dalam waktu yang tidak terbatas dan dimana saja tanpa ada batasan jarak. Dan menurut data dari Global Overview Report pada buan Januari 2021 bahwa saat ini yang menggunakan media sosial aktif di seluruh dunia angkanya sudah sampai 4,20 miliar (Kemp, 2021), data tersebut merupakan jumlah yang tercakup 53,6\% dari populasi manusia di dunia.

Media sosial banyak digunakan dalam berkomunikasi, berinteraksi, berbagi, dengan pengguna lain secara virtual untuk membentuk ikatan sosial. Menurut Nasrullah (2015), ada tiga bentuk yang mengacu pada arti bersosial dalam media sosial yaitu pengenalan, komunikasi dan kerjasama. Selanjutnya untuk mempermudah komunikasi agar lebih efektif diperlukan strategistrategi dalam berkomunikasi, dengan memperhatikan faktor penghambat dan pendukung (Effendy, 2009). Ada empat faktor yang diperhatikan pada saat penyusunan strategi berkomunikasi yaitu: 1) penentuan massa 2) pemilihan media komunikasi 3) Peninjauan pesan komunikasi 4) Kontribusi komunikator dalam komunikasi.

Kebutuhan berkomunikasi pada saat pelaksanaan kegiatan Kuliah Kerja Nyata amatlah penting, dengan memperhatikan faktor-faktor strategi dalam berkomunikasi diharapkan mampu mengatasi kondisi PPKM Darurat yang sedang terjadi. Tujuan dari pengabdian ini adalah untuk mengetahui bagaimana mahasiswa dapat melaksanakan kegiatan KKN dengan kondisi Pemberlakuan Pembatasan Kegiatan Masyarakat darurat bulan Juli sampai Agustus 2021 dan media sosial apa saja yang dipakai dalam penyampaian materi tersebut.

\section{METODE}

Metode yang digunakan adalah dengan deskriptif kualitatif dengan langkah-langkah melakukan studi literatur dan survei ke lapangan serta menyebarkan kuesioner untuk mendapatkan data. Langkah pertama yaitu survei lapangan ke kecamatan Pedurungan, meminta ijin kepada Lurah setempat untuk melakukan survei di lingkungan sekitar. Selanjutnya diarahkan oleh Lurah untuk melaksanakan kegiatan KKN dengan tetap mematuhi prokes. Kegiatan penyuluhan atau sosialisasi dilakukan secara terbatas, disini mahasiswa diminta seminimal mungkin agar tidak membuat kegiatan yang bersifat mengumpulkan warga dalam jumlah banyak. Oleh karena itu, beberapa kegiatan yang akan dilakukan oleh mahasiswa dibuat secara online melalui media sosial seperti grup WhatsApp, Instagram, Youtube, dan lain-lain. Langkah kedua yaitu melakukan studi literatur untuk menentukan teori yang digunakan serta pertanyaanpertanyaan terkait hal-hal yang ada di lapangan. Langkah ketiga menyusun pertanyaanpertanyaan yang dirangkum dalam kuesuioner yang juga diinput kedalam Google Form. Langkah keempat yaitu kuesioner dibagikan kepada mahasiswa peserta KKN yang berada dibeberapa lokasi pengabdian di Kecamatan Pedurungan, yaitu Tlogosari Wetan, Plamongansari, Pedurungan Tengah, Tlogosari Kulon, dan Muktiharjo Kidul. Dan langkah kelima berupa hasilnya dibuat diagram untuk dianalisa terkait dengan efektifitas penggunaan media sosial oleh mahasiswa selama sosialisasi KKN di kelurahan Pedurungan.

\section{HASIL DAN PEMBAHASAN}

Pengabdian kepada masyarakat yang dilaksanakan kali ini adalah di Kecamatan Pedurungan. Berikut gambar lokasi pengabdian yang berada di kota Semarang Jawa Tengah. 


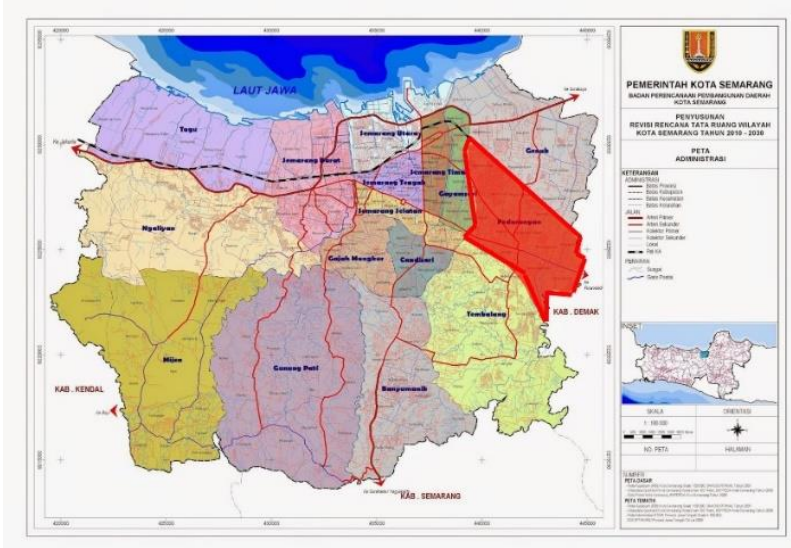

Gambar 1. Lokasi Pengabdian Kepada Masyarakat di Kecamatan Pedurungan

Pedurungan merupakan sebuah kecamatan yang berada di timur di Kota Semarang dengan luas daerah 20,72 $\mathrm{km}^{2}$, daerah Pedurungan berbatasan dengan wilayah Genuk pada bagian utara, bagian timur berbatasan dengan Mranggen, bagian selatan berbatasan dengan Tembalang, dan bagian utara berbatasan dengan Gayamsari dan Semarang Selatan. Pedurungan terbagi dalam 12 kelurahan yaitu Tlogomulyo, Pedurungan Tengah, Pedurungan Lor, Pedurungan Kidul, Penggaron Kidul, Plamongansari, Palebon, Gemah, Kalicari, Tlogosari Wetan, Tlogosari Kulon, dan Muktiharjo Kidul. Lokasi tersebut merupakan lokasi yang digunakan mahasiswa untuk melaksanakan Kuliah Kerja Nyata.

Untuk mendapatkan hasil survei di lapangan dan penyebaran kuesioner di lapangan, maka ada beberapa pertanyaan yang diajukan kepada beberapa mahasiswa antara lain terkait dengan kendala yang dihadapi mahasiswa sebelum dan pada saat pandemi, kendala-kendala yang dihadapi pada saat berlangsungnya kegiatan KKN, media sosial apa saja yang digunakan seharihari dan pada saat menyampaikan materi sosialisasi, dan lain-lain.

Sejak pandemi COVID-19 melanda mengakibatkan semua jenis aktivitas menjadi terhambat dan dengan pemerintah Indonesia mulai menyarankan gerakan stay at home (tetap dirumah) untuk mengantisipasi penyebaran virus COVID-19 di masyarakat. Anjuran tersebut juga berimbas pada kegiatan KKN, dimana mahasiswa harus berinteraksi langsung dengan masyarakat dalam setiap program kegiatan yang dilakukan. Berikut adalah prosentase perbandingan dari gerakan stay at home yang berimbas pada program kegiatan KKN.

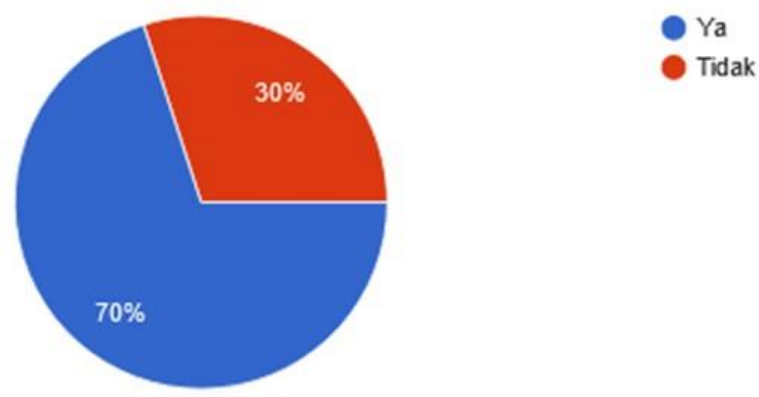

Gambar 2. Prosentase kendala aktivitas saat gerakan stay at home di berlakukan

Berdasarkan hasil survei seperti terlihat pada Gambar 2, sebanyak 70\% mahasiswa mengatakan bahwa gerakan stay at home yang dianjurkan pemerintah Indonesia mengakibatkan kendala saat beraktivitas terutama saat program kegiatan KKN berlangsung.

Selain kendala terbatasnya dalam beraktivitas, kendala-kendala lain juga muncul selama kegiatan KKN yang berlangsung di masa pandemi COVID-19, berdasarkan hasil survei yang dilakukan kendala yang paling banyak ditemukan adalah proses sosialisasi materi saat melakukan program kegiataan di masyarakat, kemudian diikuti dengan teknik penyampaian materi dari program kegiatan KKN, dan cara berkomunikasi dalam kelompok pada saat kegiatan KKN. 


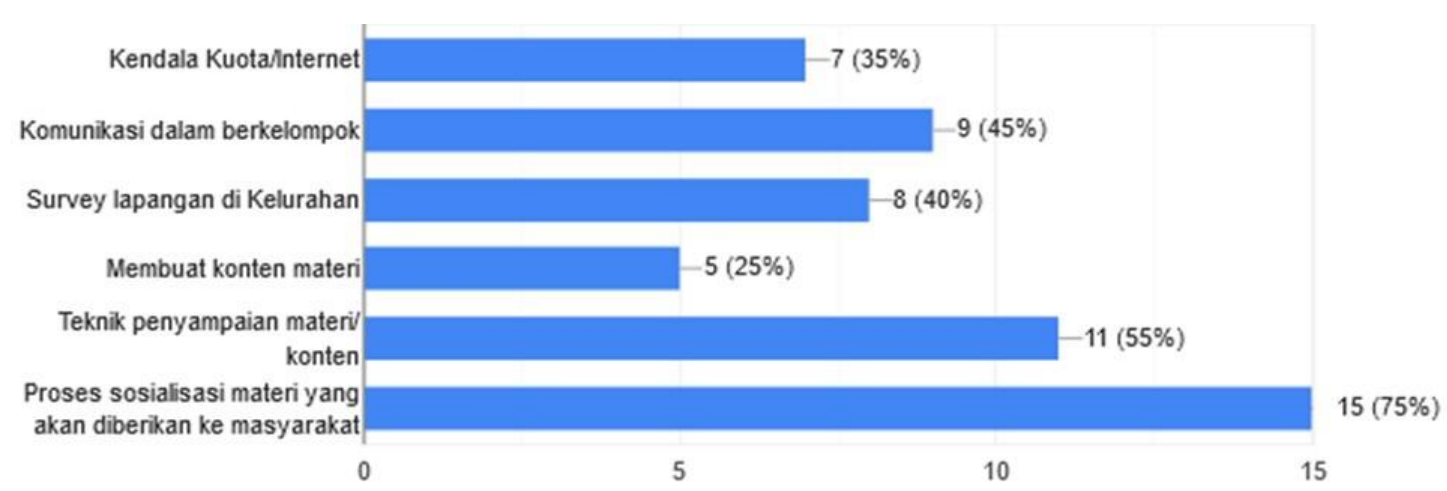

Gambar 3. Kendala saat kegiatan KKN berlangsung saat pandemi COVID-19

Selama KKN, terdapat banyak kegiatan yang dilakukan secara rutin seperti survei lapangan, berjaga di posko KKN, piket di kelurahan, menjalankan program kerja, membantu warga, dan kegiatan lainnya. Berdasarkan hasil survei pada Gambar 4 menunjukkan tidak sepenuhnya kegiatan-kegiatan yang biasa dilakukan pada saat tidak terjadi pandemi COVID-19 dapat juga dilakukkan di masa pandemi sekarang. Dimana di masa pandemi ini kegiatan-kegiatan tersebut menjadi terhambat karena anjuran pemerintah untuk tetap di rumah guna mengurangi penyebaran virus COVID-19 di masyarakat.

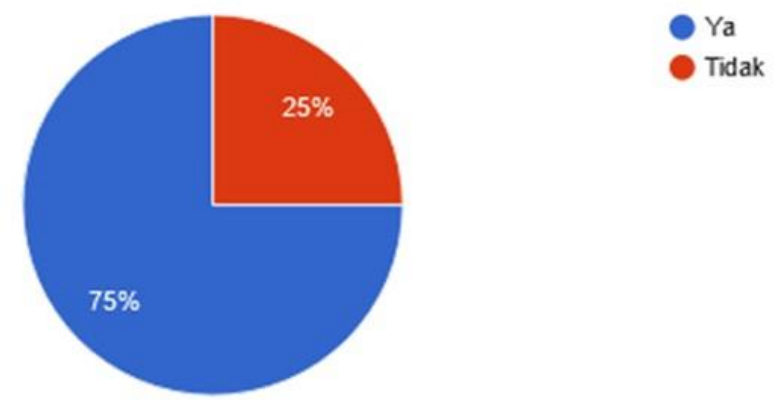

Gambar 4. Perbandingan kegiatan KKN saat dan sebelum pandemi COVID-19

Dengan anjuran dari pemerintah untuk tetap dirumah membuat terbatasnya kegiatan program kerja KKN yang dapat dilakukan di masa pandemi, membuat mahasiswa harus mampu memanfaatkan segala macam bentuk media untuk penyampaian program kerja yang telah disusun, salah satunya media digital (sosial media) untuk penyampaian materi sosialisasi ataupun lainnya dalam kegiatan KKN.

Berdasarkan hasil survei pada Gambar 5 menunjukkan sebanyak 75\% telah menggunakan media digital (sosial media) dalam penyampaian materi sosialisasi maupun kegiatan lainnya selama KKN berlangsung dan $25 \%$ kegiatan tetap dilaksanakan di lokasi dengan mematuhi ketentuan prokes.

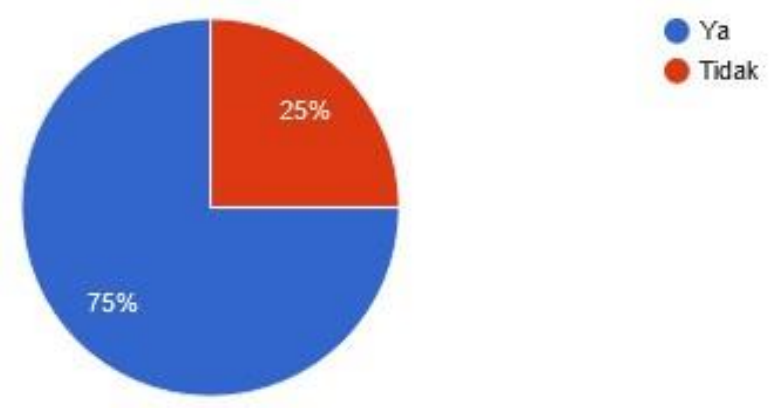

Gambar 5. Perbandingan penyampaian materi sosisalisasi selama KKN dalam bentuk digital (media sosial) 


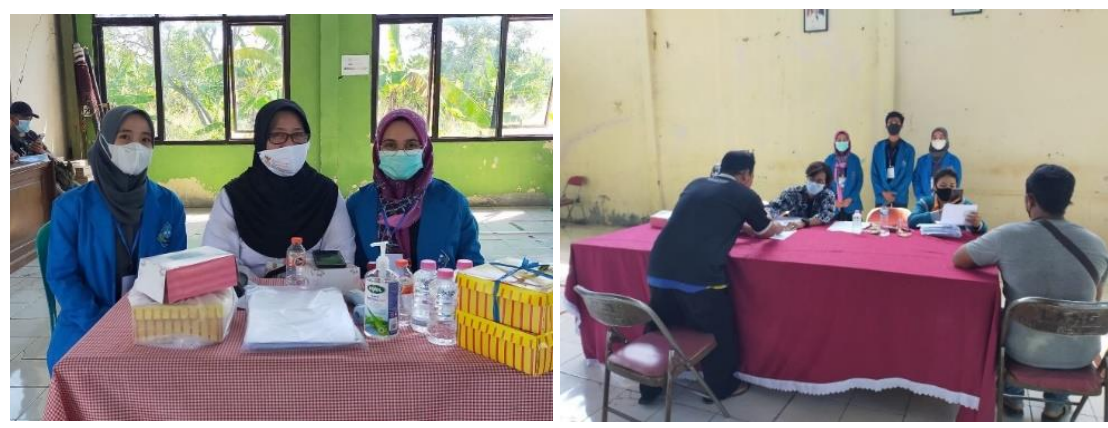

Gambar 6. Kegiatan KKN yang dilakukan di lokasi dengan memenuhi prokes yang ditentukan

Media digital (media sosial) yang digunakan dalam kegiatan KKN sangat beragam dan dengan kelebihannya masing-masing, berdasarkan hasil survei pada Gambar 7 WhatsApp adalah yang paling banyak digunakan, whatsapp merupakan aplikasi yang berbasis chatting (obrolan) dimana penggunanya dapat berkirim pesan text, gambar, ataupun video. Kemudian diikuti instagram, merupakan aplikasi sosial media dimana penggunanya dapat berbagi gambar ataupun video dan juga chatting, instagram lebih mau menjangkau banyak orang dengan fitur-fitur yang ada. Youtube paling banyak digunakan ketiga dalam penyampain materi dalam kegiatan KKN.

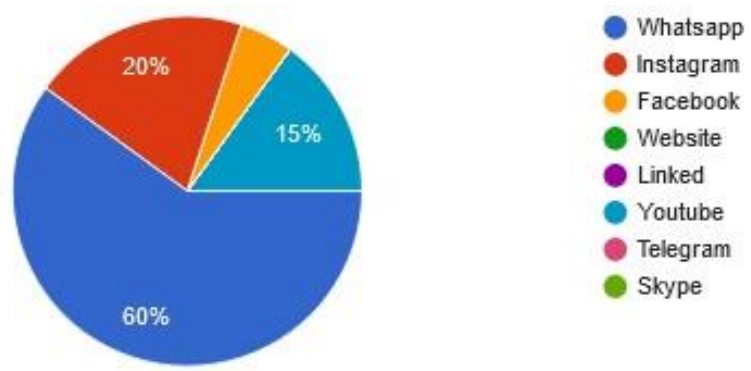

Gambar 7. Perbandingan penggunaan media sosial dalam kegiatan KKN

Tema-tema yang dipilih pada saat melaksanaan KKN di Kecamatan Pedurungan terutama pada saat PPKM Darurat yang berlaku 3 Juli sampai dengan 2 Agustus 2021 ini antara lain tema pengertian Covid dan bagaimana pencegahannya, sosialisasi hidup sehat, pembuatan jamu untuk stamina tubuh agar mencegah terpapar Covid, inovasi pembuatan handsanitizer dan masker, sosialisasi tentang kesehatan (mentaati prokes yang ditetapkan), perbaikan gizi seimbang di masa pandemi, penyuluhan terkait dengan isolasi mandiri, dan lain-lain. Berikut beberapa contoh kegiatan sosialisasi yang menggunakan media sosial instagram:

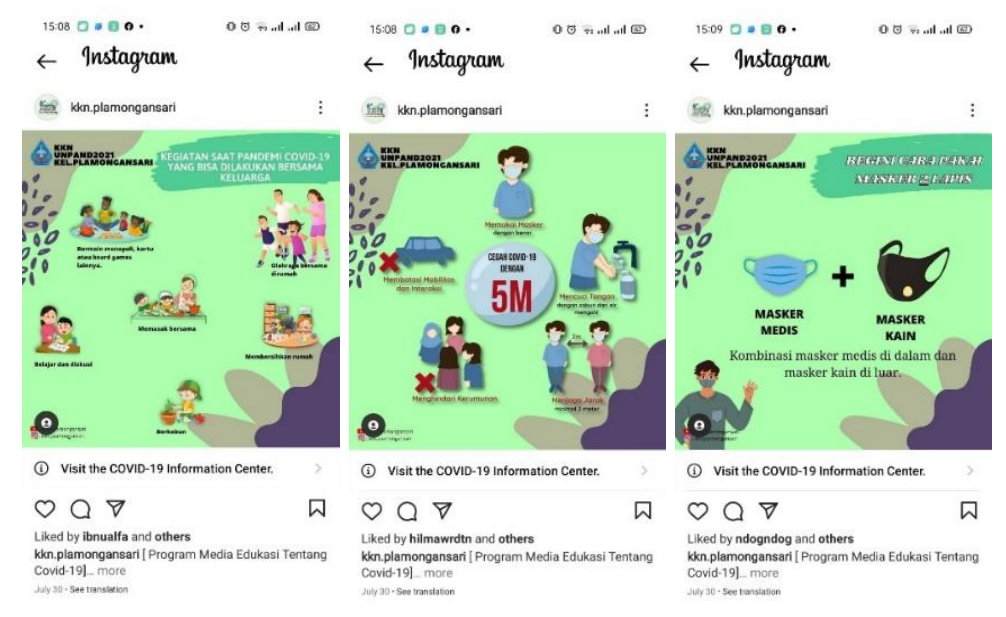

Gambar 8. Penggunaan Instagram untuk sosialisasi materi KKN di kelurahan Plamongansari 


\section{KESIMPULAN}

Kehadiran media sosial membawa dampak dalam berkomunikasi terutama pada kegiatan Kuliah Kerja Nyata mahasiswa di kecamatan Pedurungan. Cara berkomunikasi yang konvensional diubah secara drastis menjadi modern dan serba digital pada saat Pemberlakuan Pembatasan Kegiatan Masyarakat darurat. Mahasiswa maupun masyarakat dipaksa mampu beradaptasi dengan media komunikasi digital. Media sosial yang digunakan dalam menyampaikan materi penyuluhan tersebut antara lain yaitu WhatsApp, Instagram, Facebook, dan Youtube.

\section{DAFTAR PUSTAKA}

Ardiana, D. P. ., Mawati, A. T., \& dkk. (2021). Metodologi Penelitian Bidang Pendidikan. Yayasan Kita Menulis. https://books.google.co.id/books?id=P9kWEAAAQBAJ

Ardila, Y., Kusnidar, A. B., \& dkk. (2020). PENGANTAR TEKNOLOGI INFORMASI.

Effendy, O. U. (2009). Komunikasi; Teori dan Praktek. Remaja Rosdakarya.

Kaunang, F., Karim, A., \& Dkk. (2021). Konsep Teknologi Informasi. Yayasan Kita Menulis.

Kemp, S. (2021). Digital 2021: Global Overview Report. https://datareprtal.com/reports/digital2021-global-overview-report.

Marlina, L., Ardiana, D., \& Dkk. (2020). DIGITAL MARKETING. Widina Persada Bandung.

Nasrullah, R. (2015). Media Sosial; Perspektif Komunikasi, Budaya, dan Sosioteknologi. Simbiosa Rekatama Medi.

Putu, Y. A. D., \& Dona, W. A. M. (2021). Pemanfaatan Media Social Instagram sebagai Media Pembelajaran Alternatif dalam Mata Kuliah Pemrograman. SENADA, vol 4 April.

Radovilsky, Z. (2015). Designing and Implementing an E-Commerce System. Business Expert Press. 